\title{
Çarşamba ekolojik koşullarında yetiştirilen bazı standart elma çeşitlerinin verim ve meyve özellikleri
}

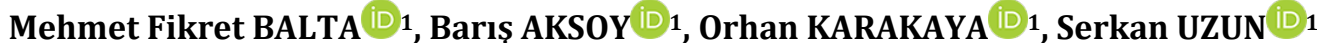

1Ordu Üniversitesi, Ziraat Fakültesi, Bahçe Bitkileri Bölümü, Ordu

Alınış tarihi: 14 Nisan 2020, Kabul tarihi: 5 Ekim 2020

Sorumlu yazar: Mehmet Fikret BALTA, e-posta: fikret_balta@hotmail.com

\section{Öz}

Çalışma, Çarşamba (Samsun) ilçesinde M9 anacı üzerine aşılı üç elma çeşidinin (Granny Smith, Royal Gala ve Galaxy Gala) verim ve meyve özelliklerini belirlemek amacıyla 2015 ve 2016 yıllarında 5 ve 6 yaşlı ağaçlarda yürütülmüştür. İncelenen elma çeşitlerinde ağaç başına verim 11.30 kg (Granny Smith)-18.91 kg (Galaxy Gala); verim etkinliği 1.69 $\mathrm{kg} \mathrm{cm}{ }^{-2}$ (Granny Smith)-3.43 $\mathrm{kg} \mathrm{cm}^{-2}$ (Galaxy Gala) arasında tespit edilmiştir. Meyve özelliklerden; meyve ağırlığı 165.23 g (Royal Gala)-187.87 g (Granny Smith), meyve eti sertliği 70.44 N (Royal Gala)-86.11 N (Granny Smith), pH değeri 2.98 (Granny Smith)-3.64 (Galaxy Gala), suda çözünebilir kuru madde miktarı \%10.24 (Granny Smith)-\%12.07 (Royal Gala) ve titre edilebilir asitlik miktarı \%0.31 (Galaxy Gala ve Royal Gala)-\%0.93 (Granny Smith) arasında değişiklik göstermiştir. Sonuç olarak, Granny Smith çeșidinden diğer çeșitlere klyasla daha kaliteli meyveler elde edilmiș ve ağaç bașına verim ve verim etkinliği bakımından ise Galaxy Gala çeşidinin daha iyi sonuçlar verdiği belirlenmiştir.

Anahtar kelimeler: Elma, Verim etkinliği, Meyve ağırlığı, Meyve eti sertliği, Suda çözünebilir kuru madde

Yield and fruit properties of some standard apple cultivars grown in Çarşamba ecological conditions

\author{
Abstract \\ The study was conducted to determine the yield and \\ fruit properties of three apple cultivars (Granny \\ Smith, Royal Gala ve Galaxy Gala) grafted on M9
}

rootstocks in Çarşamba (Samsun) district in the 2015 and 2016 years, in 5 and 6 years old trees. In apple cultivars investigated, yield per tree and yield efficiency were determined from $11.30 \mathrm{~kg}$ (Granny Smith) to $18.91 \mathrm{~kg}$ (Galaxy Gala) and $1.69 \mathrm{~kg} \mathrm{~cm}^{-2}$ (Granny Smith) and $3.43 \mathrm{~kg} \mathrm{~cm}^{-2}$ (Galaxy Gala), respectively. Fruit weight, fruit flesh firmness, $\mathrm{pH}$, total soluble solids and titratable acidity were varied between $165.23 \mathrm{~g}$ (Royal Gala) and $187.87 \mathrm{~g}$ (Granny Smith), 70.44 N (Royal Gala) and 86.11 N (Granny Smith), 2.98 (Granny Smith) and 3.64 (Galaxy Gala), 10.24\% (Granny Smith) and 12.07\% (Royal Gala), $0.31 \%$ (Galaxy Gala and Royal Gala) and 0.93\% (Granny Smith), respectively. As a conlusion, More quality fruits were obtained from Granny Smith cultivar than the others. Galaxy Gala cultivar has given better results in terms of yield per tree and yield efficiency.

Key words: Apple, Yield efficiency, Fruit weight, Firmness, Total soluble solids

\section{Giriş}

Elma, dünya üzerinde en fazla üretimi yapılan ılıman iklim meyve türlerinden biridir. Soğuk ılıman iklim koşullarını seven elma dünya üzerinde $30^{\circ}-50^{\circ}$ enlemler arasında yoğun olarak yetiştirilmektedir (Özçağıran ve ark., 2014). 2018 yılı FAO verilerine göre dünya elma üretimi yaklaşık 86.1 milyon tondur. Ülkemiz dünya elma üretiminde Çin (39 233 400 t), ABD (4 652500 t) ve Polonya'nın (3 999523 t) ardından 3625960 t üretimi ile 4. sirada yer almaktadır. Dünya elma üretiminde söz sahibi olmamıza karşın ihracatımız beklenilen düzeyde değildir (FAO, 2020). Bu durumun teknik alt yapı 
yetersizliğinin yanı sıra, pazarın tercih ettiği kaliteli çeşitlerin elma yetiştiriciliğinde kullanılmamasından kaynaklandığı ifade edilmektedir (Özongun ve ark., 2014).

Elma sahip olduğu anaç ve çeşit zenginliği ile dünyada ve ülkemizde çok farklı ekolojik koşullara uyum sağlamış durumdadır. Ülkemizde İç Anadolu, Kuzey Anadolu, Doğu Anadolu yayları arasındaki geçit bölgeleri ve Göller yöresi elma yetiştiriciliğinin yapıldığı önemli alanlardır (Atay ve ark., 2010; Özçağıran ve ark., 2014). Bu bölgelerimizde özellikle Isparta (732 036 t), Karaman (485 363 t) ve Niğde (438 327 t) illeri elma üretimi bakımından öne çıkmaktadır (TUIKK, 2020).

Günümüzde modern meyveciliğin gereklerinden olan ağaçların erken verime yatması, kaliteli ve birim alandan daha fazla ürün alınması, her yıl düzenli ürün alınması, budama, seyreltme ve hasadın daha kolay ve ekonomik yapılması dolayısıyla, son yıllarda meyve yetiştiriciliğinde kuvvetli gelişen çögür anaçlar yerine zayıf gelişim gösteren (bodur) klonal anaçların kullanılmasıyla gerçekleştirilmektedir. Elma yetiştiriciliğinin her geçen yıl artış gösterdiği ülkemizde yetiştiricilikte kullanılan M9, M27, M26 ve MM106 gibi zayıf gelişim gösteren klon anaçlar modern meyveciliğin gerekliliklerinin yerine getirilmesine olanak sağlamaktadır (Soylu ve ark., 2003). Elma yetiştiriciliğinde yoğun dikim sistemlerinde kullanılan M9, MM106 ve M26 gibi elma anaçları üzerine aşılı standart ve spur çeşitlerin meyve verim ve kalite özelliklerinin belirlenmesi konusunda dünyada çok sayıda çalışma yürütülmüştür (Bilgener ve ark., 2003; Soylu ve ark., 2003; Di-Vaio ve ark., 2009; Gjamovski ve Kiprijanovski, 2011; Pramanick ve ark., 2012; Dodange ve ark., 2012; Öztürk ve Öztürk, 2016; Öztürk ve ark., 2016; Bayazit ve ark., 2019; Şensoy ve Bostan, 2019).

Yapılan ıslah çalışmaları neticesinde mevcut çeşitlere oranla hastalık ve zararlılara karşı mukavemeti daha yüksek olan, daha uzun süre muhafaza edilebilen, verim ve kalite özellikleri bakımından üstün olan, albenisi yüksek elma çeşitleri geliştirilmektedir (Kaşka, 1997; Balta ve Kaya, 2007). Geliştirilen bu elma çeşitlerinin ekolojik istekleri birbirinden farklılık göstermektedir. $\mathrm{Bu}$ nedenle ülkemizin herhangi bir bölgesinde iyi performans gösteren elma çeşidinin diğer bölgelerimizde aynı performansı göstermesi beklenemez (Öztürk ve Öztürk, 2016). Bu bakımdan pazar isteklerini karşılayabilecek yeni ıslah edilen elma çeşitlerinin adaptasyonuna yönelik yapılacak çalışmalar ülkemiz elma yetiştiriciliğinin gelişimine katkı sağlaması ve üreticilerin yanlış çeşit seçimi sonucunda ekonomik kayıplarının önlenmesi bakımından önemlidir. Bunun yanı sıra ülkemizde yeni çeşitlerin adaptasyonu ve introdüksiyonu ile ilgili yapılan çalışmaların azlığı, elma üretimimize kıyasla ihracat değerlerimizdeki düşüklüğünün sebepleri arasında gösterilebilir (Özongun ve ark., 2014).

Bu çalışma Çarşamba (Samsun) ekolojik koşullarında yetiştirilen M9 anacı üzerine aşılı Granny Smith, Royal Gala ve Galaxy Gala elma çeşitlerinin verim ve meyve özelliklerinin belirlenmesi amacıyla yürütülmüştür.

\section{Materyal ve yöntem}

\section{Materyal}

Çalışma, Çarşamba (Samsun) ilçesinde M9 anacı üzerine aşlı Granny Smith, Royal Gala ve Galaxy Gala çeşitleri ile 2011 yılında tesis edilmiş bodur elma bahçesinde 2015 (dikimden sonra 5. yll) ve 2016 (dikimden sonra 6. yıl) yıllarında yürütülmüștür. Deneme alanında yer alan ağaçlar $1.1 \times 4.0 \mathrm{~m}$ aralıklar ile dikilmiş ve merkezi lider terbiye sistemiyle budanmıştır. Çalışma süresince teknik ve kültürel uygulamalar düzenli olarak yapılmıştır. Ağaçlar damla sulama yöntemi kullanılarak sulanmıștır.

Çalışmanın yürütüldüğü Çarşamba ilçesinde 2015 yılında en düşük aylık ortalama sıcaklık $6.9^{\circ} \mathrm{C}$ ile ocak ayında, en yüksek ise $24.6^{\circ} \mathrm{C}$ ile ağustos ayında; en düşük aylık toplam yağış miktarı $18.5 \mathrm{~mm}$ ile aralık ayında, en yüksek ise $179.6 \mathrm{~mm}$ ile ağustos ayında gerçekleşmiştir. 2016 yılında ise en düşük aylık ortalama sıcaklık $4.9^{\circ} \mathrm{C}$ ile aralık ayında, en yüksek ise $25.2^{\circ} \mathrm{C}$ ile ağustos ayında; en düşük aylık toplam yağış miktarı $0.3 \mathrm{~mm}$ ile haziran ayında, en yüksek ise $199.9 \mathrm{~mm}$ ile ocak ayında gerçekleşmiş̧tir (MGM, 2020).

\section{Yöntem}

Çalışma, 3 tekerrürlü ve her tekerrürde 5 ağaç olacak şekilde tesadüf parselleri deneme desenine göre planlanmış ve her bir çeşide ait 15 ağaç, toplamda ise 45 ağaç kullanılmıştır. İncelenen elma çeşitlerinin performanslarının belirlenmesi amacıyla verim ve meyve özellikleri incelenmiştir.

İncelenen elma çeşitlerinde, ağaç başına verim $(\mathrm{kg})$ hasattan önce ağaç üzerindeki meyvelerin sayılması ve ortalama meyve ağırlığı ile çarpılmasıyla belirlenmiştir. Verim etkinliği değeri $\left(\mathrm{kg} \mathrm{cm}^{-2}\right)$ ağaç 
başına elde edilen verim değerlerinin gövde kesit alanına bölünmesi ile hesaplanmıştır. Kalem çapı aşı yerinden itibaren $10 \mathrm{~cm}$ yukarıdan iki farklı yönde ölçülerek, ortalaması alınmış ve $\pi r^{2}$ formülü kullanılarak gövde kesit alanı hesaplanmıştır. Dekara verim (ton) değeri ise 1 da alana dikilebilecek ağaç sayının hesaplanarak, ağaç başına elde edilen verim değeri ile çarpılması sonucu hesaplanmıştır (Dousti, 2010).

Meyve özellikleri her bir tekerrürde 10 meyvede belirlenmiștir. Meyve ağırlığı 0.01 g'a duyarlı dijital hassas terazi (Desis, EHB 300, Türkiye), meyve eti sertliği penetrometrenin (FT-327, İtalya) 11.1 mm'lik ucu kullanılarak ve meyvenin boyutsal özellikleri ise (meyve eni, genişliği ve boyu) 0.01 mm'ye duyarlı dijital kumpas (Mitutoyo, Japonya) yardımıyla belirlenmiştir (Öztürk ve ark., 2016; Şensoy ve Bostan, 2019). Kimyasal özellikler çeşitlerden elde edilen süzülmüş meyve suyunda belirlenmiştir. $\mathrm{pH}$ ise dijital $\mathrm{pH}$ metre (Mettler Toledo, Amerika) ve suda çözünebilir kuru madde miktarı (SÇKM) (\%) ise dijital refraktrometre (Hanna, Amerika) kullanılarak belirlenmiștir. Titre edilebilir asitlik miktarı (TEA) (\%) elde edilen meyve suyunun saf su ile seyreltilmesi $(1: 1 ; \mathrm{v}: \mathrm{v})$ ve $\mathrm{pH}$ metrede okunan değerin 8.1'e gelinceye kadar $0.1 \mathrm{~N}$ $\mathrm{NaOH}$ ile titre edilmesiyle belirlenmiștir (Öztürk ve ark., 2016).

\section{Bulgular ve tartışma}

Araştırmada ağaç başına ve dekara verim değerleri bakımından incelenen elma çeșitleri arasında önemli farklılıklar belirlenmiştir $(\mathrm{p}<0.05)$. En yüksek ağaç bașına verim Galaxy Gala çeșidinde (18.91 kg) belirlenirken, en düşük ise Granny Smith çeşidinde $(11.30 \mathrm{~kg}$ ) belirlenmiștir. İncelenen elma çeşitlerinde dekara verim en yüksek 4.102 ton ile Galaxy Gala çeşidinde, en düşük ise 2.450 ton ile Granny Smith çeşidinde tespit edilmiştir (Çizelge 1). M9 anacı üzerine aşılı farklı elma çeşitlerinde ağaç başına verim değerini Ceylan (2008) Sazlıca (Niğde) ilçesinde yetiştirilen Galaxy Gala çeşidinde dikimden sonra 13. ve 14 . yillarda ortalama $11.27 \mathrm{~kg}$ ve Mondial Gala çeşidinde ortalama 11.40 kg; Çulha (2010) Laçin (Çorum) yöresinde yetiştirilen Granny Smith çeşidinde dikimden sonra 4. ve 5. ylllarda ortalama $15.70 \mathrm{~kg}$; Dousti (2010) Ankara ilinde yetiştirilen Galaxy Gala çeşidinde dikimden sonra 4. ve 5. yillarda ortalama $6.90 \mathrm{~kg}$ ve Granny Smith çeşidinde ortalama $4.41 \mathrm{~kg}$; Baytekin ve Akça (2011) Tokat ilinde yetiştirilen Galaxy Gala çeşidinde dikimden sonra 4. yılda 27.74 kg; Ünüvar ve Pırlak
(2016) Karaman yöresinde yetiștirilen Granny Smith çeşidinde dikimden sonra 4. yılda $16.30 \mathrm{~kg}$ ve Galaxy Gala çeşidinde 10.84 kg; Öztürk ve ark. (2016) Ordu yöresinde yetiştirilen Granny Smith çeşidinde dikimden sonra 4. yılda $11.02 \mathrm{~kg}$ ve Mondial Gala çeşidinde 13.29 kg; Şensoy ve Bostan (2019) Ulubey (Ordu) ilçesinde yetiştirilen Granny Smith çeşidinde dikimden sonraki ilk dört yıllık ortalamaya göre 2.58 kg olarak belirlemişlerdir. Mevcut çalışmada Gala grubu çeşitlerinden elde edilen ağaç başına verim değerleri Granny Smith çeşidinin verim değerinden yüksek bulunmuştur. Benzer sonuçlar yürütülen farklı çalışmalarda da görülmektedir. Mevcut çalışmada incelenen elma çeşitlerinin ağaç başına verim değerleri araştırıcıların benzer yaştaki ağaçlardan elde ettiği bulgulardan genel olarak yüksek bulunurken, Baytekin ve Akça (2011)'nın Galaxy Gala çeşidinden elde ettiği verim değerlerinden ise düşük bulunmuştur. Ağaç başına verim değeri bakımından görülen farklılıkların ekolojik koşullardan, kültürel ve teknik uygulamalardan kaynaklı olabileceği düșünülmektedir.

Çizelge 1. İncelenen elma çeşitlerinde dikimden sonra 5. (2015) ve 6. (2016) ylllarda ortalama ağaç başına verim (kg), dekara verim (ton $\left.\mathrm{da}^{-1}\right)$ ve verim etkinliği $(\mathrm{kg}$ $\mathrm{cm}^{-2}$ ) değerleri

\begin{tabular}{cccc}
\hline Çeşit & $\begin{array}{c}\text { Ağaç başına verim } \\
\left(\mathrm{kg} \mathrm{ağaç-1)}^{-1}\right.\end{array}$ & $\begin{array}{c}\text { Dekara } \\
\text { verim } \\
\left(\text { ton da }^{-1}\right)\end{array}$ & $\begin{array}{c}\text { Verim etkinliği } \\
\left(\mathrm{kg} \mathrm{cm}^{-2}\right)\end{array}$ \\
\hline Granny Smith & $11.30 \mathrm{~b}^{*}$ & $2.450 \mathrm{~b}$ & $1.69 \mathrm{~b}$ \\
Royal Gala & $14.15 \mathrm{ab}$ & $3.069 \mathrm{ab}$ & $2.47 \mathrm{ab}$ \\
Galaxy Gala & $18.91 \mathrm{a}$ & $4.102 \mathrm{a}$ & $3.43 \mathrm{a}$ \\
\hline
\end{tabular}

* Aynı sütunda aynı harf ile gösterilen değerler arasındaki farklılık önemsizdir $(\mathrm{p}<0.05)$.

Verim etkinliği bakımından incelenen elma çeşitleri arasında önemli farklılıklar belirlenmiştir $(\mathrm{p}<0.05)$. Verim etkinliği en yüksek Galaxy Gala (3.43 $\left.\mathrm{kg} \mathrm{cm}^{-2}\right)$, en düşük ise Granny Smith (1.69 $\mathrm{kg} \mathrm{cm}^{-2}$ ) çeşidinde tespit edilmiştir (Çizelge 1). Elmada verim etkinliği değerini Dousti (2010) Ankara ilinde M9 anacl üzerine aşılı Galaxy Gala çeşidinde dikimden sonra 4. ve 5. ylllarda ortalama $0.93 \mathrm{~kg} \mathrm{~cm}^{-2}$ ve Granny Smith çeşidinde ortalama $0.69 \mathrm{~kg} \mathrm{~cm}^{-2}$; Baytekin ve Akça (2011) Tokat yöresinde M9 anacı üzerine aşılı Galaxy Gala çeşidinde dikimden sonra 4. yılda 0.40 $\mathrm{kg} \mathrm{cm}$ cm $^{-2}$ Bayazit ve ark. (2019) Erdemli (Mersin) ilçesinde M9 anacı üzerine aşılı Mondial Gala çeşidinde dikimden sonra 8 . yılda $0.56 \mathrm{~kg} \mathrm{~cm}^{-2}$ olarak tespit etmişlerdir. İncelenen elma çeşitlerinin verim 
etkinliği değerleri araştırıcıların bulgularından yüksek bulunmuştur. Görülen farklılıkların ekolojik faktörlerden, ağaç yaşından ve bakım şartlarından kaynaklı olabileceği düşünülmektedir.

Meyve ağırlığı bakımından incelenen elma çeşitleri arasında önemli farklılıklar belirlenmiştir $(p<0.05)$. En yüksek meyve ağırlığı Granny Smith çeşidinde (187.87 g) belirlenirken, en düşük ise Royal Gala ve Galaxy Gala çeşitlerinde (165.23 g ve 167.42 g, sırasıyla) belirlenmiștir (Çizelge 2). M9 anacı üzerine aşılı farklı elma çeşitleri ile yürütülen çalışmalarda meyve ağırlı̆̆ını Ceylan (2008) Sazlıca yöresinde yetiştirilen Granny Smith çeşidinde 196.77 g, Galaxy Gala çeşidinde $147.45 \mathrm{~g}$ ve Mondial Gala çeşidinde 150.80 g; Çulha (2010) Çorum ekolojik koşullarında yetiştirilen Granny Smith çeşidinde 194.53 g; Dousti (2010) Ankara yöresinde yetiştirilen Granny Smith çeşidinde 186.95 g ve Galaxy Gala çeşidinde 156.50 g; Baytekin ve Akça (2011) Tokat ekolojik koşullarında yetiştirilen Galaxy Gala çeşidinde 165.37 g; Öztürk ve ark. (2016) Ordu ilinde yetiştirilen Granny Smith çeşidinde 207.10 g ve Mondial Gala çeşidinde 186.90 g; Öztürk ve Öztürk (2016) Samsun ekolojik koşullarında yetiştirilen Granny Smith çeșidinde 163.6 g; Boyacı (2019) Kırşehir ekolojik koşullarında yetiştirilen Granny Smith çeşidinde $168.08 \mathrm{~g}$ ve Mondial Gala çeşidinde 209.16 g; Şensoy ve Bostan (2019) Ulubey yöresinde yetiştirilen Granny Smith çeşidinde 191.10 g olduğunu bildirmişlerdir. İncelenen elma çeşitlerinde meyve ağırlı̆̆ı bakımından elde edilen bulgular araştırıcıların bulgularından kısmen farklılık göstermektedir. Meyve ağırlığı bakımından görülen farklılıkların ekolojik faktörlerden, ağaç üzerindeki ürün yükünden, teknik ve kültürel uygulamalardan kaynaklı olabileceği düşünülmektedir.

Çizelge 2. İncelenen elma çeşitlerinin meyve ağırlığı (g) ve meyve eti sertliği $(\mathrm{N})$

\begin{tabular}{ccc}
\hline Çeşit & Meyve ağırlı̆̆ $(\mathrm{g})$ & Meyve eti sertliği (N) \\
\hline Granny Smith & $187.87 \mathrm{a}^{*}$ & $86.11 \mathrm{a}$ \\
Royal Gala & $165.23 \mathrm{~b}$ & $70.44 \mathrm{~b}$ \\
Galaxy Gala & $167.42 \mathrm{~b}$ & $69.56 \mathrm{~b}$ \\
\hline
\end{tabular}

* Aynı sütunda aynı harf ile gösterilen değerler arasındaki farklılık önemsizdir $(\mathrm{p}<0.05)$.

Meyve eti sertliği bakımından incelenen elma çeşitleri arasında önemli farklılıklar belirlenmiştir $(p<0.05)$. Araştırmada en yüksek meyve eti sertliği Granny Smith (86.11 N) çeşidinde, en düşük ise
Galaxy Gala ve Royal Gala (69.56 N ve70.44 N) çeşitlerinde saptanmıștır (Çizelge 2). M9 anacı üzerine aşlı elma çeşitlerinde meyve eti sertliğini Ceylan (2008) Sazlıca yöresinde Granny Smith çeşidinde 82.21 N, Galaxy Gala çeşidinde $75.43 \mathrm{~N}$ ve Mondial Gala çeşidinde 73.52 N; Çulha (2010) Çorum ekolojik koşullarında Granny Smith çeşidinde 63.91 N, Dousti (2010) Ankara ilinde Granny Smith çeşidinde $87.05 \mathrm{~N}$ ve Galaxy Gala çeşidinde $74.45 \mathrm{~N}$; Öztürk ve ark. (2016) Ordu yöresinde Granny Smith çeşidinde $77.89 \mathrm{~N}$ ve Mondial Gala çeşidinde 63.43 N; Öztürk ve Öztürk (2016) Samsun ekolojik koşullarında yetiştirilen Granny Smith çeşidinde 78.3 N; Boyacı (2019) Kırşehir ekolojik koşullarında yetiştirilen Granny Smith çeşidinde $57.88 \mathrm{~N}$ ve Mondial Gala çeşidinde 53.37 N; Şensoy ve Bostan (2019) Ulubey (Ordu) yöresinde Granny Smith çeşidinde $84.07 \mathrm{~N}$ olarak tespit etmişlerdir. Mevcut çalışmada meyve eti sertliği bakımından elde edilen bulgular araştırıcıların bulgularına yakın olduğu, görülen bazı farklılıkların ise ekolojik koşullardan, kültürel uygulamalardan ve meyvenin olgunluk durumundan kaynaklı olabileceği düşünülmektedir.

İncelenen elma çeşitler arasında meyve boyutları bakımından önemli farkllıklar belirlenmiştir $(p<0.05)$. İncelenen elma çeşitlerinde meyve eni $70.74 \mathrm{~mm}$ (Granny Smith)-74.34 mm (Royal Gala); meyve genişliği $72.67 \mathrm{~mm}$ (Granny Smith)-76.91 mm (Royal Gala) ve meyve boyu $62.29 \mathrm{~mm}$ (Granny Smith)-65.90 mm (Royal Gala) arasında ölçülmüştür (Çizelge 3). Meyve boyutları bakımından en yüksek değer Granny Smith çeşidinden elde edilirken, en düşük değer ise Royal Gala ve Galaxy Gala çeşitlerinde belirlenmiştir. M9 anacı üzerine aşılı farklı elma çeşitleri ile yürütülen çalışmalarda meyve eni ve meyve boyu değerlerini sırasıyla Çulha (2010) Laçin yöresinde Granny Smith çeşidinde $77.51 \mathrm{~mm}$ ve $71.63 \mathrm{~mm}$; Ceylan (2008) Sazlıca ilçesinde Galaxy Gala çeşidinde $70.87 \mathrm{~mm}$ ve $58.32 \mathrm{~mm}$ ve Mondial Gala çeşidinde $71.36 \mathrm{~mm}$ ve $58.82 \mathrm{~mm}$; Baytekin ve Akça (2011) Tokat yöresinde Galaxy Gala çeşidinde $72.80 \mathrm{~mm}$ ve $66.00 \mathrm{~mm}$; Öztürk ve ark. (2016) Ordu ekolojik koşullarında Granny Smith çeşidinde 77.60 $\mathrm{mm}$ ve $69.07 \mathrm{~mm}$ ve Mondial Gala çeşidinde 74.02 mm ve 67.99 mm; Öztürk ve Öztürk (2016) Samsun ekolojik koşullarında Granny Smith çeşidinde 74.27 $\mathrm{mm}$ ve $62.12 \mathrm{~mm}$; Boyacı (2019) Kırşehir ilinde yetiştirilen Granny Smith çeşidinde $72.89 \mathrm{~mm}$ ve $63.20 \mathrm{~mm}$ ve Mondial Gala çeşidinde $76.87 \mathrm{~mm}$ ve $65.82 \mathrm{~mm}$; Şensoy ve Bostan (2019) Ulubey ilçesinde Granny Smith çeşidinde $75.77 \mathrm{~mm}$ ve $69.61 \mathrm{~mm}$ 
olarak ölçmüşlerdir. İncelenen elma çeșitlerinde meyvenin boyutsal özellikleri bakımından elde edilen bulgular araştırıcıların bulgularıyla benzer bulunmuştur.

Çizelge 3. İncelenen elma çeşitlerinin meyve eni, meyve genişliği ve meyve boyu (mm)

\begin{tabular}{cccc}
\hline Çeşit & $\begin{array}{c}\text { Meyve eni } \\
(\mathrm{mm})\end{array}$ & $\begin{array}{c}\text { Meyve } \\
\text { genişliği }(\mathrm{mm})\end{array}$ & $\begin{array}{c}\text { Meyve boyu } \\
(\mathrm{mm})\end{array}$ \\
\hline Granny Smith & $74.34 \mathrm{a}^{*}$ & $76.91 \mathrm{a}$ & $65.90 \mathrm{a}$ \\
Royal Gala & $70.74 \mathrm{~b}$ & $72.67 \mathrm{~b}$ & $62.29 \mathrm{~b}$ \\
Galaxy Gala & $71.00 \mathrm{~b}$ & $73.23 \mathrm{~b}$ & $62.58 \mathrm{~b}$ \\
\hline
\end{tabular}

* Aynı sütunda aynı harf ile gösterilen değerler arasındaki farklılık önemsizdir $(\mathrm{p}<0.05)$.

İncelenen elma çeşitleri arasında $\mathrm{pH}$, SÇKM ve TEA değerleri bakımından önemli farklılıklar belirlenmiștir $(p<0.05)$. İncelenen elma çeşitlerinde pH 2.98 (Granny Smith)-3.64 (Galaxy Gala), SÇKM \%10.24 (Granny Smith)-\%12.07 (Royal Gala) ve TEA \%0.31 (Galaxy Gala ve Royal Gala)-\%0.93 (Granny Smith) arasında tespit edilmiştir. pH, SÇKM ve TEA değerleri bakımdan Galaxy Gala ve Royal Gala çeşitleri istatistiksel olarak benzer grupta yer almıştır (Çizelge 4). Genel olarak değerlendirildiğinde, Granny Smith çeșidinin pH ve SÇKM değerlerinin Gala grubu çeşitlerden daha düșük; TEA değerlerinin ise daha yüksek olduğu belirlenmiștir. $\mathrm{Bu}$ durum, karakteristik olarak Granny Smith çeșidinin ekşi; Gala grubu çeșitlerin ise tatlı tada sahip olması ile açılanabilir.

Farklı bölgelerde M9 anacı üzerine aşılı farklı elma çeşitleri ile yürütülen çalışmalarda Ceylan (2008) Sazlıca ilçesinde SÇKM değerini Granny Smith çeşidinde \%12.20 ve Galaxy Gala çeşidinde \%13.16; Çulha (2010) Çorum ilinde Granny Smith çeşidinde pH değerini 3.39, SÇKM değerini \%12.94 ve TEA değerini \%2.22; Dousti (2010) Ankara ekolojik koşullarında Granny Smith çeşidinde SÇKM değerini $\% 12.45$ ve TEA değerini \%1.66, Galaxy Gala çeşidinde SÇKM değerini \%14.40 ve TEA değerini \%0.47; Baytekin ve Akça (2011) Tokat ekolojik koşullarında Galaxy Gala çeșidinde pH değerini 3.85, SÇKM değerini \%8.83 ve TEA değerini \%0.69; Öztürk ve ark. (2016) Ordu yöresinde Granny Smith çeșidinde $\mathrm{pH}$ değerini 3.23, SÇKM değerini \%9.13 ve TEA değerini \%0.67; Mondial Gala çeşidinde $\mathrm{pH}$ değerini 3.81 , SÇKM değerini $\% 11.25$ ve TEA değerini \%0.27; Öztürk ve Öztürk (2016) Samsun ekolojik koşullarında Granny Smith çeşidinde $\mathrm{pH}$ değerini 3.74 , SÇKM değerini $\% 11.37$ ve TEA değerini \%0.90; Boyacı (2019) Kırşehir yöresinde yetiştirilen Granny Smith çeşidinde pH değerini 3.31 ve SÇKM değerini \%11.16, Mondial Gala çeşidinde pH değerini 3.54 ve SÇKM değerini \%15.41; Şensoy ve Bostan (2019) Ulubey (Ordu) ekolojik koşullarında Granny Smith çeşidinde $\mathrm{pH}$ değerini 3.55 , SÇKM değerini $\% 11.53$ ve TEA değerini $\% 0.79$ olarak tespit etmişlerdir. İncelenen elma çeşitlerinin kimyasal içeriklerinin benzer ekolojide yetiştirilen çeşitler ile uyumlu olduğu, buna karşıllı farklı ekolojide yetiştirilen çeşitlerden elde edilen değerlerden ise düşük olduğu belirlenmiştir. Bu durum kimyasal özellikler üzerine ekolojik koşulların etkili olduğunu göstermektedir. Bunun yanı sıra görülen bazı farklılıkların ise bakım koşullarından ve meyvenin olgunluk durumundan kaynaklı olabileceği düşünülmektedir.

Çizelge 4. İncelenen elma çeşitlerinin $\mathrm{pH}$, SÇKM ve TEA değerleri

\begin{tabular}{cccc}
\hline Çeşit & $\mathrm{pH}$ & SÇKM (\%) & TEA (\%) \\
\hline Granny Smith & $2.98 \mathrm{~b}^{*}$ & $10.24 \mathrm{~b}$ & $0.93 \mathrm{a}$ \\
Royal Gala & $3.61 \mathrm{a}$ & $12.07 \mathrm{a}$ & $0.31 \mathrm{~b}$ \\
Galaxy Gala & $3.64 \mathrm{a}$ & $11.95 \mathrm{a}$ & $0.31 \mathrm{~b}$ \\
\hline
\end{tabular}

* Aynı sütunda aynı harf ile gösterilen değerler arasındaki farklılık önemsizdir $(\mathrm{p}<0.05)$.

\section{Sonuç}

Çarşamba (Samsun) yöresinde M9 anacı üzerine aşılı Granny Smith, Royal Gala ve Galaxy Gala çeşitleri ile yürütülen çalışmada, verim özellikleri bakımından Galaxy Gala ve tüketicinin albenisini etkileyen meyve iriliği bakımından ise Granny Smith çeşidi daha iyi sonuçlar vermiştir. Sonuç olarak, farklı ekolojilerde benzer elma çeşitleri ile yapılan çalışmaların sonuçları dikkate alındığında incelenen elma çeşitlerinin verim ve meyve özellikleri bakımından iyi bir performans gösterdikleri ifade edilebilir. Özellikle verim parametreleri bakımından kayda değer sonuçların olduğu görülmüştür. Bu bakımdan incelenen çeşitlerden Galaxy Gala ve Royal Gala güzlük, Granny Smith ise kışlık çeşit olarak bölgede elma yetiştiriciliği için tavsiye edilebilir.

\section{Teșekkür}

$\mathrm{Bu}$ çalışma Ordu Üniversitesi Bilimsel Araştırma Projeleri Koordinasyon Birimini (ODU-BAP) tarafından TF-1631 nolu proje ile desteklenmiștir. 


\section{Kaynaklar}

Atay, A. N., Atay, E., \& Koyuncu, F. (2010). Dünya elma islah programlarına genel bir bakış. Bahçe, 39(1), 31-44.

Balta, M. F., \& Kaya, T. (2007). Cebegirmez ve Bey Elma çeşitlerinin morfolojik ve pomolojik karakterleri. $V$. Ulusal Bahçe Bitkileri Kongresi, 1, 687-691.

Bayazit, S., Kılıç, D., \& Gündüz, K. (2019). Performance of Mondial Gala apple cultivars grafted on M9 apple rootstock in the Mediterranean region of Turkey. Mustafa Kemal Üniversitesi Tarım Bilimleri Dergisi, 24(1), 43-47.

Baytekin, S., \& Akça, Y. (2011). M9 elma anacı üzerine aşılı farklı elma çeşitlerinin performanslarının belirlenmesi. Gaziosmanpaşa Üniversitesi Ziraat Fakültesi Dergisi, 1, 45-51.

Bilginer, Ş., Akbulut, M., \& Kaplan, N. (2003). Samsun koşullarında elma yetiştiriciliğinde anaçxçeşitxdikim sıklığı kombinasyonlarının saptanması Üzerine Bir Araștırma. Türkiye IV. Ulusal Bahçe Bitkileri Kongresi, 52-54.

Boyacı, S. (2019). Bazı elma (Malus domestica L.) çeşitlerinin fenolojik ve pomolojik özelliklerinin belirlenmesi. Türkiye Tarımsal Araștırmalar Dergisi, 6(1), 73-79.

Ceylan, F. B. (2008). Bodur ve yarı bodur anaçlar üzerine aşılı bazı elma çeşitlerinin Niğde ekolojik şartlarında fenolojik ve pomolojik özelliklerinin tespiti. Selçuk Üniversitesi, Fen Bilimleri Enstitüsü, Yüksek Lisans Tezi. Konya, 56s.

Çulha, A. E. (2010). Çorum ekolojik şartlarında M9 anacına aşılı bazı elma çeşitlerinin fenolojik ve pomolojik özelliklerinin tespiti. Selçuk Üniversitesi, Fen Bilimleri Enstitüsü, Yüksek Lisans Tezi. Konya, 54s.

Di Vaio, C., Cirillo, C., Buccheri, M., \& Limongelli, F. (2009). Effect of interstock (M. 9 and M. 27) on vegetative growth and yield of apple trees (cv "Annurca"). Scientia Horticulturae, 119(3), 270-274.

Dodange, M. R., Shakouri, M. J., \& Hamzehei, Z. (2012). Effects of $M$ and MM Rootstocks on Agromorphological Characteristics of. World Applied Sciences Journal, 20(7), 1043-1046.

Dousti, S. (2010). Braeburn, Fuji, Gala, Granny Smith, Jonagold ve Top Red elma çeşitlerinde M9 anacı üzerindeki genç ağaçların verim ve bazı meyve özelliklerinin yaz ayları düşük nemli karasal iklim koşullarında incelenmesi. Ankara Üniversitesi, Fen Bilimleri Enstitüsü, Yüksek Lisans Tezi. Ankara.

FAO, (2020). Food and Agriculture Organization of the United Nations. http://www.fao.org/faostat/ en/\#data/QC. (Erişim tarihi: 02.03.2020).
Gjamovski, V., \& Kiprijanovski, M. (2011). Influence of nine dwarfing apple rootstocks on vigour and productivity of apple cultivar 'Granny Smith'. Scientia Horticulturae, 129(4), 742-746.

Kaşka, N. (1997). Türkiye'de elma yetiştiriciliğinin önemi, sorunları ve çözüm yolları. Yumuşak Çekirdekli Meyveler Sempozyumu, 2-5.

MGM, (2020). Meteoroloji 10. Genel Müdürlüğü Samsun. http://www.samsun.mgm.gov.tr/. (Erişim tarihi: 05.03.2020).

Özçağıran, R., Ünal, A., Özeker, E., \& İsfendiyaroğlu, M. (2014). Elma. Ilıman İklim Meyve Türleri, Yumuşak Çekirdekli Meyveler, Cilt: II. Ege Üniversitesi Ziraat Fakültesi Yayınları. Ege Üniversitesi Ziraat Fakültesi Ofset Atölyesi, Bornova, İzmir, 166s.

Özongun, Ş., Dolunay, E. M., Öztürk, G., \& Pektaş, M. (2014). Eğirdir (Isparta) şartlarında bazı elma çeşitlerinin performansları. Meyve Bilimi, 1(2), 21-29.

Öztürk, A., Öztürk, B. (2016). Samsun ekolojisinde yetiştirilen standart bazı elma çeșitlerinin fenolojik ve pomolojik özelliklerinin belirlenmesi. Anadolu Tarım Bilimleri Dergisi, 31(1), 1-8.

Öztürk, B., Uzun, S., Bektaş, E., Yarılgaç, T., Karakaya, M., Karakaya, M., Karakaya, O., Gün, S., \& Turga, E. (2016). M9 Anacı üzerine aşılı bazı elma çeşitlerinin Ordu ilinde verim ve kalite özelliklerinin belirlenmesi. Bahçe, 45, 492-497.

Pramanick, K. K., Kishore, D. K., Singh, R., \& Kumar, J. (2012). Performance of apple (Malus $x$ domestica Borkh) cv. Red Spur on a new apple rootstock in high density planting. Scientia Horticulturae, 133, 37-39.

Soylu, A., Ertürk, Ü., Mert, C., \& Öztürk, Ö. (2003). MM 106 anacı üzerine aşılı elma çeşitlerinin Görükle koşullarındaki verim ve kalite özelliklerinin incelenmesi-II. Uludağ Üniversitesi Ziraat Fakültesi Dergisi, 17(2), 57-65.

Şensoy, M., \& Bostan, S. Z. (2019). Ulubey ilçesinde (Ordu) MM 106 ve M 9 anaçları üzerindeki 'Granny Smith' elma çeşidinin ilk ylllar verim ve pomolojik özellikleri. Akademik Ziraat Dergisi, 8(1), 9-12.

TUIK, (2020). Türkiye İstatistik Kurumu. https://biruni.tuik.gov.tr. (Erişim tarihi: 02.03.2020).

Ünüvar, G., \& Pirlak, L. (2016). Karaman ekolojik şartlarında M9 anacına aşılı bazı elma çeşitlerinin fenolojik ve pomolojik özellikleri. Nevșehir Bilim ve Teknoloji Dergisi, Özel sayı, 96-106. 